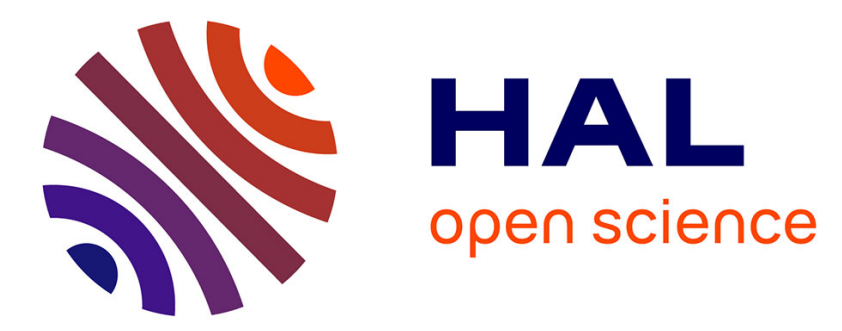

\title{
A preliminary study on anti-hypoxia activity of yak milk powder in vivo
}

Wei Zhang, Shaozong Wu, Jialu Cao, Haimei Li, Yan Li, Jiguo He, Liebing Zhang

\section{> To cite this version:}

Wei Zhang, Shaozong Wu, Jialu Cao, Haimei Li, Yan Li, et al.. A preliminary study on antihypoxia activity of yak milk powder in vivo. Dairy Science \& Technology, 2014, 94 (6), pp.633-639. 10.1007/s13594-014-0184-3 . hal-01234883

\section{HAL Id: hal-01234883 \\ https://hal.science/hal-01234883}

Submitted on 27 Nov 2015

HAL is a multi-disciplinary open access archive for the deposit and dissemination of scientific research documents, whether they are published or not. The documents may come from teaching and research institutions in France or abroad, or from public or private research centers.
L'archive ouverte pluridisciplinaire HAL, est destinée au dépôt et à la diffusion de documents scientifiques de niveau recherche, publiés ou non, émanant des établissements d'enseignement et de recherche français ou étrangers, des laboratoires publics ou privés. 


\title{
A preliminary study on anti-hypoxia activity of yak milk powder in vivo
}

\author{
Wei Zhang • Shaozong Wu • Jialu Cao • Haimei Li • \\ Yan Li • Jiguo He $\cdot$ Liebing Zhang
}

Received: 11 April 2014 /Revised: 12 July 2014 / Accepted: 17 July 2014 /

Published online: 27 August 2014

(C) INRA and Springer-Verlag France 2014

\begin{abstract}
Yak milk is the main source of dietary protein, fat, and micronutrients for Tibetan residents, who live at a high altitude and oxygen-deficient environment. The anti-hypoxia activity of yak milk powder (YMP) was investigated in mouse hypoxia models, using the normobaric hypoxia test, sodium nitrite toxicosis test, and hematological parameters analyses. The results showed that YMP could prolong the survival time under both normobaric hypoxia and sodium nitrite toxicosis conditions by $15.7 \%-$ $17.3 \%$ and $13.9 \%-15.1 \%$, respectively, and increase the levels of red blood cells (RBC) and blood hemoglobin $(\mathrm{Hb})$. Furthermore, YMP was better than cow milk powder (CMP) in anti-hypoxia activity. YMP could be explored as a novel anti-hypoxia functional food ingredient.
\end{abstract}

Keywords Yak milk powder - Anti-hypoxia activity Mouse hypoxia models

\section{Introduction}

China has the largest population of yaks in the world, approximately 14 million, that accounts for $95 \%$ of the total world population of yak (He et al. 2011). Yak milk ranks in third place after cow and buffalo milks in economic importance in China (Zhong et al. 2006). The yak is an iconic symbol of Tibet, which can survive under harsh environment, such as high altitude (2,500 to 5,000 m), deficient oxygen, and low temperature $\left(-40{ }^{\circ} \mathrm{C}\right)$. Yak milk is the main source of dietary protein, fat, and micronutrients for Tibetan residents who adapt well at a high altitude and low oxygen environment (Dong et al. 2007). Yak milk contains high contents of total solids

\footnotetext{
W. Zhang $\cdot \mathrm{S}$. Wu $\cdot$ J. Cao $\cdot$ H. Li $\cdot$ J. He $\cdot$ L. Zhang $(\bowtie)$

College of Food Science and Nutritional Engineering, China Agricultural University, No. 17, Qinghua East RoadHaidian DistrictBeijing 100083, China

e-mail: liebzhang@gmail.com

Y. Li

School of Food and Chemical Engineering, Beijing Technology and Business University, Beijing 100048, China
} 
(16.9\%-17.9\%), protein (4.9\%-5.9\%), and fat (5.5\%-7.5\%) (Li et al. 2009; Wu et al. 2009; He et al. 2011). It has been speculated that adaptation of the Tibetan to the environment is related to their diet rich in yak milk.

The high-altitude stress and hypoxia symptom are very common for visitors, but not for the residents. Hypoxia, which occurs during acute and chronic vascular disease, cancer, and stroke, is defined as a decrease in the normal level of tissue oxygen tension (Xie et al. 2010). Some chemical drugs, such as acetazolamide, dexamethasone, and nimodipine, had a significant anti-hypoxia activity (Lee et al. 2007). However, most of these drugs also bring some side effects. Therefore, many studies began to investigate the anti-hypoxia activity of natural materials in recent years. Some plant polysaccharide and terpenoid extracts have been reported to have anti-hypoxia activity (Chen et al. 2009; Zhang and Dai 2011; Jia 2011). Although milk is one of the major foods in the world, there are no investigations on anti-hypoxia activity of milk, especially yak milk, which contains many nutrients and bioactive compounds. Here, we made a preliminary study on anti-hypoxia activity of yak milk powder (YMP) compared to cow milk powder (CMP), using mouse hypoxia models.

\section{Materials and methods}

\subsection{Samples}

Yak milk samples were manually milked from 120 yaks in three Tibetan areas, including Hong Yuan, Lu Qu, and Lin Xia, China, respectively, in June. Cow milk sample, as a positive control, was obtained from Beijing in June. All raw milk samples were pasteurized at $62.5^{\circ} \mathrm{C}$ for $30 \mathrm{~min}$, and then lyophilized and stored at $-80{ }^{\circ} \mathrm{C}$ until use. The protein and fat contents $(\%, \mathrm{~g} / \mathrm{g})$ are 26.5 and 32.8 , respectively, in yak milk powder (YMP), and 24.4 and 31.7, respectively, in cow milk powder (CMP).

\subsection{Animals}

One hundred male BALB/c mice (16-18 g, special pathogen-free (SPF) grade, approval no. SCXK-2007-004) were purchased from the Academy of Military Medical Sciences (AMMS), Beijing, China. The mice were housed at five per cage in a room maintained at $23 \pm 1{ }^{\circ} \mathrm{C}, 50 \%-60 \%$ relative humidity, and air circulation all the time, with a 12/12-h light-dark cycle, in Beijing Centers for Diseases Control and Prevention. They had free access to distilled water and balanced murine diet provided by AMMS, containing $(\%, \mathrm{~g} / \mathrm{g})$ crude protein $(18 \%)$, crude fat $(4 \%)$, crude fiber $(5.0 \%)$, Ca $(1-1.8 \%)$, P $(0.6 \%-1.2 \%)$, moisture $(10 \%)$, and ash $(8 \%)$. All mice received humane care in compliance with the guide of Beijing Centers for Diseases Control and Prevention and also in strict accordance with the NIH Guide for the Care and Use of Laboratory Animals (NIH, 2002).

\subsection{Experimental design}

The mice were randomized into five groups with 20 mice in each group after 1-week adaptation: control group (control, distilled water), cow milk powder group (CMP, 5.2 
mg. $\mathrm{g}^{-1}$ bw.day ${ }^{-1}, \mathrm{~g}^{-1}$ bw.day ${ }^{-1}=$ per gram body weight per day), low-dose yak milk powder group (YMP-L, $2.6 \mathrm{mg} \cdot \mathrm{g}^{-1} \mathrm{bw}^{-}$day $^{-1}$ ), middle-dose yak milk powder group (YMP-M, $5.2 \mathrm{mg} \cdot \mathrm{g}^{-1}$ bw.day ${ }^{-1}$ ), high-dose yak milk powder group (YMP-H, $7.8 \mathrm{mg} \cdot \mathrm{g}^{-1}$ bw.day $^{-1}$ ). The YMP and CMP were dissolved in distilled water. All mice were administrated at $0.2 \mathrm{~mL} .10 \mathrm{~g}^{-1} \mathrm{bw}$ day $^{-1}$ by gavage. Body weights were measured weekly. The 20 mice in each group were divided into two subgroups. One group $(n=10)$ was firstly used to determine hematological parameters at 28 days and then used for normobaric hypoxia test at 30 days; the other group $(n=10)$ was used for sodium nitrite toxicosis test at 30 days.

\subsection{Normobaric hypoxia test}

The normobaric hypoxia test was carried out according to Zhang and Dai (2011). One hour after last treatment, each mouse was put into a $250-\mathrm{mL}$ wide-necked bottle with $5 \mathrm{~g}$ medical soda lime inside, and then the bottle was sealed with vaseline. When the mouse could not breathe, the survival time of oxygen deprivation was immediately recorded.

\subsection{Sodium nitrite toxicosis test}

The sodium nitrite toxicosis test was carried out according to Xie et al. (2010). One hour after last treatment, the weights of mice were measured. Sodium nitrite was dissolved in distilled water. Then, each mouse was subcutaneously injected with sodium nitrite $\left(220 \mathrm{mg} \cdot \mathrm{kg}^{-1} \mathrm{bw}\right)$. The survival time of sodium nitrite toxicosis was immediately recorded after cardiac arrest.

\subsection{Hematological parameters analysis}

One hour after last treatment, a $20-\mu \mathrm{L}$ volume of blood sample was precisely collected with a capillary tube, using the inner canthus bleeding method, and then was put into heparinized tube. The hematological parameters, including red blood cells (RBC) and the blood hemoglobin $(\mathrm{Hb})$, were immediately measured by an automatic hematological analyzer (Nihon Kohden, Japan).

\subsection{Statistical analyses}

The experimental data were expressed as mean $\pm \mathrm{SD}$. The data were subjected to oneway analysis of variance and Duncan's multiple range test was performed to determine the significant difference among samples within the $95 \%$ confidence interval, while Dunnett's T3 test was conducted if data have statistic heteroschedasticity.

\section{Results and discussion}

In this study, there were no significant differences among the control, CMP, and YMP groups in body weight after 4-week feeding ( $P>0.05$; Table 1). YMP prolonged significantly the survival time of oxygen deprivation mice by $15.7 \%-17.3 \%$ in the 
Table 1 Effect of YMP on BALB/c mice body weight

\begin{tabular}{llr} 
Group & $\begin{array}{l}\text { Body weight (g) } \\
\text { Initial (week 0) }\end{array}$ & Final (week 4) \\
\hline Control & $19.53 \pm 2.85^{\mathrm{a}}$ & $27.24 \pm 2.02^{\mathrm{b}}$ \\
CMP & $19.61 \pm 2.44^{\mathrm{a}}$ & $27.18 \pm 2.37^{\mathrm{b}}$ \\
YMP-L & $19.88 \pm 2.09^{\mathrm{a}}$ & $27.15 \pm 1.38^{\mathrm{b}}$ \\
YMP-M & $19.71 \pm 2.16^{\mathrm{a}}$ & $27.03 \pm 2.03^{\mathrm{b}}$ \\
YMP-H & $19.98 \pm 2.07^{\mathrm{a}}$ & $26.97 \pm 1.16^{\mathrm{b}}$
\end{tabular}

The mice in YMP-L, YMP-M, and YMP-H groups were treated with the YMP $\left(2.6,5.2,7.8 \mathrm{mg}^{-1} \mathrm{~g}^{-1}\right.$. day $\left.{ }^{-1}\right)$. The mice in the CMP group were treated with CMP $\left(5.2 \mathrm{mg}^{-\mathrm{g}^{-1}} \mathrm{bw}\right.$. day $\left.{ }^{-1}\right)$, the mice in the control group were treated with distilled water $\left(0.2 \mathrm{~mL} .10 \mathrm{~g}^{-1} \mathrm{bw}\right.$. day $\left.{ }^{-1}\right)$, once a day for 28 days. Values are means $\pm \operatorname{SD}(n=20)$. Significant differences between the five groups are noted by different letters within a column $(P<0.05)$

$C M P$ cow milk powder, YMP yak milk powder

normobaric hypoxia test (Fig. 1). YMP also showed a significant effect on increasing the survival time of toxicosis mice in the sodium nitrite toxicosis test (Fig. 2). The survival time of YMP-M mice extended $15.3 \%$ and $14.7 \%$ compared to CMP mice in both normobaric hypoxia test and sodium nitrite toxicosis test. Both normobaric hypoxia test and sodium nitrite toxicosis test were widely used for the evaluation of anti-hypoxia activity (Chen et al. 2009; Zhang and Dai 2011). Sodium nitrite could translate bivalent iron into trivalent iron in hemoglobin, which induced that hemoglobin could not carry oxygen, and led to cell death (Gupta and Briyal 2004; Prabhakaran et al. 2004).

The levels of $\mathrm{RBC}$ and $\mathrm{Hb}$ in three YMP groups were higher than those in the control group (Table 2). In addition, the levels of $\mathrm{RBC}$ and $\mathrm{Hb}$ were $7.1 \%$ and $12.0 \%$ higher, respectively, in YMP-M group than in CMP group (Table 2). The levels of RBC and $\mathrm{Hb}$ are the major determinants of oxygen transport and utilization (Calbet et al.

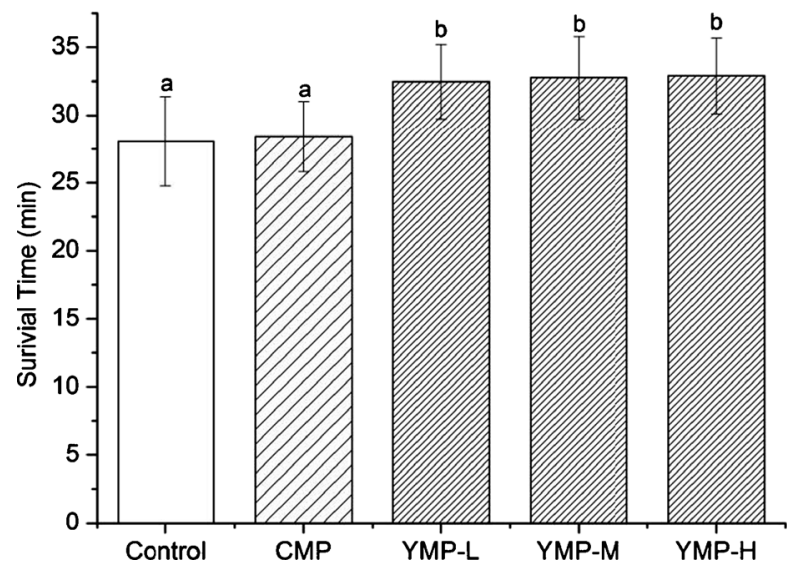

Fig. 1 Effect of YMP on survival time of BALB/c mice in normobaric hypoxia test. The mice in YMP-L, YMP-M, and YMP-H groups were treated with the YMP $\left(2.6,5.2,7.8 \mathrm{mg} . \mathrm{g}^{-1} \mathrm{bw}\right.$. day $\left.{ }^{-1}\right)$. The mice in CMP group were treated with CMP $\left(5.2{\mathrm{mg} . \mathrm{g}^{-1} \mathrm{bw} \text {. day }}^{-1}\right)$, the mice in the control group were treated with distilled water $\left(0.2 \mathrm{~mL} .10 \mathrm{~g}^{-1} \mathrm{bw}\right.$. day $\left.{ }^{-1}\right)$, once a day for 30 days. $C M P$ cow milk powder, $Y M P$ yak milk powder. Values are means $\pm \mathrm{SD}(n=10)$. Significant differences between the five groups are noted by $a$ and $b(P<0.05)$ 


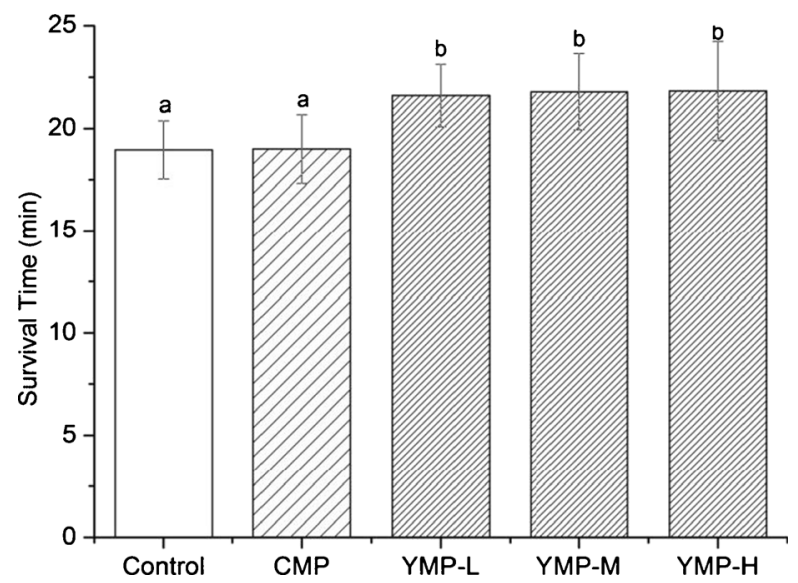

Fig. 2 Effect of YMP on survival time of BALB/c mice in sodium nitrite toxicosis test. The mice in YMP-L, YMP-M, and YMP-H groups were treated with the YMP $\left(2.6,5.2,7.8 \mathrm{mg} . \mathrm{g}^{-1} \mathrm{bw}\right.$. day $\left.{ }^{-1}\right)$. The mice in CMP group were treated with CMP $\left(5.2{\mathrm{mg} . \mathrm{g}^{-1} \mathrm{bw} \text {. day }}^{-1}\right)$, the mice in the control group were treated with distilled water $\left(0.2 \mathrm{~mL} .10 \mathrm{~g}^{-1} \mathrm{bw}\right.$. day $\left.{ }^{-1}\right)$, once a day for 30 days. $C M P$ cow milk powder, $Y M P$ yak milk powder. Values are means $\pm \mathrm{SD}(n=10)$. Significant differences between the five groups are noted by $a$ and $b(P<0.05)$

2006). High levels of $\mathrm{Hb}$ and RBC could enhance the endurance of hypoxia (Xie et al. 2010), which could be the mechanism of anti-hypoxia activity of YMP.

The contents of fat and protein between YMP and CMP are at the same levels, which ensured mice in YMP-M and CMP groups received the same levels of fat and protein. The results of anti-hypoxia activity of YMP were better than CMP, which could be associated with higher proportions of branched chain amino acid, conjugated linoleic acid (CLA) and Fe in yak milk (Li et al. 2011; He et al. 2011; Liu et al. 2011). These nutrients could exert synergetic effects for the anti-hypoxia activity of YMP. It is well known that Fe could contribute to the synthesis of RBC, which may explain the high levels of RBC and $\mathrm{Hb}$ in YMP groups. CLA inhibited prolyl hydroxylase (PHD) protein expression and elevated the expression of hypoxia inducible factor (HIF) related transcriptional factors, which could improve hypoxia-dependent process (Zhang and Li 2012). The inhibition of PHD could increase the expression of HIF which could

Table 2 Effect of YMP on RBC and HB levels in BALB/c mice

\begin{tabular}{lcc}
\hline Group & RBC $\left(1 \times 10^{12} \mathrm{~L}^{-1}\right)$ & $\mathrm{HB}\left(\mathrm{g} \cdot \mathrm{L}^{-1}\right)$ \\
\hline Control & $9.70 \pm 0.37^{\mathrm{a}}$ & $137.8 \pm 8.8^{\mathrm{a}}$ \\
CMP & $9.72 \pm 0.50^{\mathrm{a}}$ & $140.4 \pm 10.6^{\mathrm{ab}}$ \\
YMP-L & $10.27 \pm 0.44^{\mathrm{b}}$ & $147.6 \pm 4.5^{\mathrm{bc}}$ \\
YMP-M & $10.28 \pm 0.61^{\mathrm{b}}$ & $149.2 \pm 10.0^{\mathrm{c}}$ \\
YMP-H & $10.39 \pm 0.62^{\mathrm{b}}$ & $154.4 \pm 7.0^{\mathrm{c}}$ \\
\hline
\end{tabular}

The mice in YMP-L, YMP-M, and YMP-H groups were treated with the YMP (2.6, 5.2, 7.8 mg. $\left.\mathrm{g}^{-1} \mathrm{bw}_{\text {. day }}{ }^{-1}\right)$. The mice in the CMP group were treated with CMP $\left(5.2 \mathrm{mg}^{-\mathrm{g}^{-1} \mathrm{bw} \text {. day }}{ }^{-1}\right)$, the mice in the control group were treated with distilled water $\left(0.2 \mathrm{~mL} .10 \mathrm{~g}^{-1} \mathrm{bw}\right.$. day $\left.{ }^{-1}\right)$, once a day for 28 days. Values are means $\pm \operatorname{SD}(n=10)$. Significant differences between the five groups are noted by different letters within a column $(P<0.05)$

$C M P$ cow milk powder, YMP yak milk powder, $R B C$ red blood cells, $H b$ blood hemoglobin 
enhance oxygen availability by promoting erythropoiesis and angiogenesis (Appelhoff et al. 2004; Lee et al. 2004). Thus, CLA may be one of the bioactive compounds for the anti-hypoxia activity of YMP. Therefore, YMP could be explored as a novel antihypoxia agent.

\section{Conclusions}

YMP improved the survival time of mice under hypoxia conditions by increasing the oxygen-delivery capacity. Furthermore, YMP was better than CMP in anti-hypoxia activity. This study could contribute to the application of yak milk powder as a functional ingredient for hypoxia related disease. However, further research needs to be carried out to evaluate the mechanism at cellular and molecular levels.

Acknowledgments We are grateful for financial support from the Special Fund for Agro-scientific Research in the Public Interest (201303085), the earmarked fund for Modern Agro-industry Technology Research System (CARS-37), the National Natural Science Foundation of China (Grant no. 31171714), the Planning Subject of "the twelfth five-year-plan" in National Science and Technology for the Rural Development in China (2013BAD18B05-02, 2013BAD18B12-04, 2013BAD18B12-05), the Postdoctoral Science Foundation of China (2013M541087) and Synergetic Innovation Center of Food Safety and Nutrition.

Conflict of interest There is no conflict of interest concerning this manuscript.

\section{References}

Appelhoff RJ, Tian Y-M, Raval RR, Turley H, Harris AL, Pugh CW, Ratcliffe PJ, Gleadle JM (2004) Differential function of the prolyl hydroxylases PHD1, PHD2, and PHD3 in the regulation of hypoxiainducible factor. J Biol Chem 279(37):38458-38465

Calbet JA, Lundby C, Koskolou M, Boushel R (2006) Importance of hemoglobin concentration to exercise: acute manipulations. Respir Physiol Neurobiol 151(2):132-140

Chen CJ, Wang WY, Wang XL, Dong LW, Yue YT, Xin HL, Ling CQ, Li M (2009) Anti-hypoxic activity of the ethanol extract from Portulaca oleracea in mice. J Ethnopharmacol 124(2):246-250

Dong S, Long R, Kang M (2007) Milking performance of China yak (Bos grunniens). Afr J Agric Res 2(3): 052-057

Gupta YK, Briyal S (2004) Animal models of cerebral ischemia for evaluation of drugs. India J Physiol Pharmacol 48(4):379-394

He S, Ma Y, Wang J, Li Q, Yang X, Tang S, Li H (2011) Milk fat chemical composition of yak breeds in China. J Food Compos Anal 24(2):223-230

Jia D (2011) Composition and effect of anti-hypoxia of Chinese medicinal plant mixture. J Med Plants Res 5(11):2298-2301

Lee J-W, Bae S-H, Jeong J-W, Kim S-H, Kim K-W (2004) Hypoxia-inducible factor (HIF-1) $\alpha$ : its protein stability and biological functions. Exp Mol Med 36(1):1-12

Lee KA, Roth RA, LaPres JJ (2007) Hypoxia, drug therapy and toxicity. Pharmacol Ther 113(2):229-246

Li H, Ma Y, Dong A, Wang J, Li Q, He S, Maubois JL (2009) Protein composition of yak milk. Dairy Sci Technol 90(1):111-117

Li H, Ma Y, Li Q, Wang J, Cheng J, Xue J, Shi J (2011) The chemical composition and nitrogen distribution of chinese yak (maiwa) milk. Int J Mol Sci 12(8):4885-4895

Liu HN, Ren FZ, Jiang L, Ma ZL, Qiao HJ, Zeng SS, Gan BZ, Guo HY (2011) Fatty acid profile of yak milk from the Qinghai-Tibetan Plateau in different seasons and for different parities. J Dairy Sci 94(4):1724-1731

Prabhakaran K, Li L, Borowitz JL, Isom GE (2004) Caspase inhibition switches the mode of cell death induced by cyanide by enhancing reactive oxygen species generation and PARP-1 activation. Toxicol Appl Pharmacol 195(2):194-202 
Wu X-H, Luo Z, Yu L, Ren F-Z, Han B-Z, Nout MR (2009) A survey on composition and microbiota of fresh and fermented yak milk at different Tibetan altitudes. Dairy Sci Technol 89(2):201-209

Xie Y, Jiang S, Su D, Pi N, Ma C, Gao P (2010) Composition analysis and anti-hypoxia activity of polysaccharide from Brassica rapa L. Int J Biol Macromol 47(4):528-533

Zhang CX, Dai ZR (2011) Anti-hypoxia activity of a polysaccharide extracted from the Sipunculus nudus L. Int J Biol Macromol 49(4):523-526

Zhang J, Li D (2012) Effect of conjugated linoleic acid on inhibition of prolyl hydroxylase 1 in hearts of mice. Lipids Health Dis 11:22

Zhong J, Chen Z, Zhao S, Xiao Y (2006) Classification of ecological types of the Chinese yak. Acta Ecol Sin 26(7):2068-2072 